\title{
Community Action in the Fight Against Adolescent Pregnancy in the Village of Anono, Southern Côte d'Ivoire
}

\author{
Adou Serge Judicaël Anoua ${ }^{1 *}$, Mohamed Sow ${ }^{2}$, Zié Adama Ouattara ${ }^{3}$, Kouaka Michel Kepo ${ }^{4}$ \\ ${ }^{1}$ Department of Anthropology \& Sociology, Research and Training Unit Communication, Milieu and Society, \\ Alassane Ouattara University, Bouaké, Côte d'Ivoire. \\ ${ }^{2}$ Department of Anthropology \& Sociology, Alassane Ouattara University, Bouaké, Côte d'Ivoire. \\ ${ }^{3}$ Center of Research for Development (CRD), Alassane Ouattara University, Bouaké, Côte d'Ivoire. \\ ${ }^{4}$ Radiology Service, Ministry of Health and Public Hygiene, Anyama, Côte d'Ivoire.
}

*Corresponding Author: Adou Serge Judicaël Anoua, Department of Anthropology \& Sociology, Alassane Ouattara University, Bouaké, Côte d'Ivoire

\begin{abstract}
Adolescent pregnancy is a major problem in Côte d'Ivoire. Although this high-risk reproductive behaviour is well studied, state institutions fail to keep it under control. For this reason, participatory research was conducted as a community health promotion strategy in the village of Anono, southern Côte d'Ivoire. The goal was to help the community to find ways to reduce its rate of adolescent pregnancy and improve adolescent girls' well-being. The research was qualitative in nature, with the Ébrié community of Anono as its study population. It consisted of three stages: social mobilisation, community diagnosis, and activity planning. The main problems identified in the community were grandparents urging adolescents to procreate, validation of adolescent motherhood through the tambruya ceremony, families ignoring cases of adolescent rape, family poverty, adolescent girls' financial insecurity, adolescent girls exchanging sexual favours for financial relief, lack of sexuality education, adolescent girls' ignorance of their sexuality, and failure to use birth control. The solutions that were adopted were educating grandparents about adolescent pregnancy, educating adolescents about sexuality, promoting income-generating activities for adolescent girls, and excluding adolescent girls from the tambruya ceremony. The ultimate success of this project depends on the commitment and participation of the whole community of Anono.
\end{abstract}

Keywords: adolescent pregnancy, maternal morbidity, participation, commitment, community health, reproductive health

\section{INTRODUCTION}

Adolescent pregnancy represents a high-risk reproductive behaviour which is particularly widespread in developing countries. According to estimates by WHO, as many as 21 million young women become pregnant every year in developing regions, and 12 million of them bring a child into the world (WHO, 2020). It is noteworthy that adolescent pregnancy does not only have negative consequences for the health of adolescent girls, it is also a grave issue from the point of view of socioeconomic development, especially in the developing world. The various complications of pregnancy and childbirth have been identified as the leading cause of mortality among girls aged from 15 to 19 in low- and middle-income countries (WHO, 2012). Adolescent pregnancy also has adverse social and economic repercussions. On the whole, its impact on adolescent girls, on their children and on society in general is by no means to be underestimated (McIntyre \& WHO, 2007). It is well known that an unmarried pregnant adolescent girl is at risk of falling victim to stigmatisation, ostracism or even violence on the part of her family or her peers (UNFPA, 2015). If she is married, she could also be victimised by her husband. Furthermore, pregnancy and motherhood are liable to seriously compromise the future educational and professional opportunities of adolescent girls.

Côte d'Ivoire is not an exception to the prevalence of adolescent pregnancy in developing countries. Its adolescent fertility rate for girls aged from 15 to 19 has been calculated at 129 births per 1000 adolescent girls, which is relatively high (MSHP, 2016). Moreover, the proportion of adolescent girls who have started their reproductive life exhibits a drastic increase with age. Specifically, it rises from 
$5 \%$ at 15 years of age to $50 \%$ at 19 years of age, by which point $42 \%$ of adolescent girls have already had at least one live birth. The latter percentage is strikingly higher in rural regions $(46 \%)$ of Côte d'Ivoire in comparison with urban regions (19\%) (MSLS, INS et ICF International, 2012). It should also be noted that a great deal of adolescent pregnancies are unintended and unwanted, which shows that adolescent girls face difficulties in controlling their fertility (OECD Development Centre, 2017). In the course of 2018, the Cocody-Bingerville health district of Côte d'Ivoire recorded an alarming total of 840 cases of child and adolescent pregnancies in schools, with the age of the pregnant girls ranging from 10 to 16, according to the 2018 annual report of the Direction de la mutualité et des œuvres sociales en milieu scolaire (DMOSS, Directorate for Mutual Aid and Social Welfare in Schools).

In the literature, a wide array of factors conducive to adolescent pregnancy have so far been pointed out. In general, theoretical and empirical studies have revealed that the incidence of adolescent pregnancy is affected by a community's norms and values relating to subjects such as sexuality, marriage, family and fertility. Rwenge (1999), for example, discuss this relation in the context of Cameroun (see also Blum \& Gates, 2013). An important role is also played by the economic, political, and institutional context, as shown by Yakubu \& Salisu (2018) in reference to Sub-Saharan Africa in general. The specific sociocultural and economic factors which have been identified by researchers in different African countries include adolescent marriage (McHunu et al., 2012; Ogori, Shitu \& Yunusa, 2013), lack of support from family members (Krugu et al., 2016; Wood \& Hendricks, 2017), peer influence (Salami, Ayegboyin \& Adedeji, 2014; Mushwana et al., 2015), sexual violence based on a power imbalance between the two sexes (McCleary-Sills et al., 2013; Atuyambe et al., 2015), and the poverty of adolescent girls' families (Gyan, 2013; Lambani, 2015). Additionally, lack of education reproductive and sexual health education in particular - among adolescent girls has been repeatedly noted as a determinant of adolescent pregnancy (Jewkes et al., 2001; Warenius et al., 2006; Okigbo \& Speizer, 2015). Although all of these factors have been documented and scientifically elucidated, state institutions in developing countries are still struggling to keep the phenomenon adolescent pregnancy in check. The cited scientific studies themselves have failed to propose realistic strategies to combat this high-risk reproductive behaviour adequately.

In light of this state of affairs, participatory action research appears to be a promising alternative method for reducing the rate of adolescent pregnancy, which is why it was chosen for this study carried out in the village of Anono. Participatory action research falls within a constructivist framework and seeks to instigate social change with a bias in favour of the exploited, oppressed or simply ignored social groups of community (Townsend et al., 2000). It consequently runs counter to scientific orthodoxy, which insists on researchers' objectivity, as discussed by Rains and Ray (1995). The fundamental aim of participatory action research is to address a the real needs of a population and to help its members to develop their knowledge and skills, as pointed out by Mason and Boutilier (1996). True to Freirean principles, this type of research lays great emphasis on the political dimension that is immanent in knowledge production, more specifically on the role played by knowledge in power and control (Reason, 1994; Hagey, 1997), and endeavours to tackle social problems which by their very nature require collective solutions (Park et al., 1993). It is based on the fundamental premise that the active participation of community members makes research and social health promotion more effective, more meaningful, and more culturally appropriate (Green, Daniel \& Novick, 2001; Sullivan et al., 2001). The social actors of the community targeted by participatory research must be willing to take action and defend their common interests, neglected by society as a whole. They must join forces to bring about social change together, as explained by Demange, Henry and Préau (2012).

The study presented here is an example of this research approach applied to the domain of community health, in particular to the phenomenon of adolescent pregnancy in the village of Anono of Côte d'Ivoire, where it is quite prevalent. A large number of adolescent girls which are currently pregnant or have already become mothers can be encountered in the community. Becoming pregnant so early in life has potentially grave consequences. For many women, pregnancy is a happy event in their lives, but when it occurs at too young an age, it is instead an ordeal. It exposes adolescent girls to a range of serious medical and socioeconomic problems and jeopardises their future. It is for these reasons that it was decided to initiate community action in the village of Anono through participatory research. The ultimate goal of the research was to help the community to find ways to reduce its rate 
of adolescent pregnancy and to consequently improve the well-being of its female adolescent members.

\section{Materials AND MethodS}

The scope of the research was the village of Anono, which lies in the middle of the Riviera neighbourhood in the commune of Cocody, which is in turn a part of the city of Abidjan, the economic capital of Côte d'Ivoire. The autochthonous villagers belong to the cultural and ethnic group known as Ébrié, which belongs to the broader Akan group. In 2014, the population of the village of Anono was estimated at 21,965 inhabitants by the general population and housing census of Côte d'Ivoire. Much like in the rest of Abidjan, there has been immigration to Anono motivated by a pursuit for socioeconomic advantages, which has transformed the village into a sort of dormitory for the upper-crust commune of Cocody, as Brenoum et al. (2017) have put it.

The field research was carried out between the dates of $29^{\text {th }}$ of July and $12^{\text {th }}$ of August 2020. The study was qualitative in nature and it was conducted with a constructivist approach. It made headway in raising awareness among the villagers of Anono with the aim of mobilising them and engaging them in addressing the alarming issue of adolescent pregnancy, which affects not only local adolescent girls but the entire community. Several target groups were composed for the purposes of the study, the largest one consisting of adolescent girls, with or without children, since they are the social category which is most directly concerned by the phenomenon under study and the factors which underlie it. Consequently, they were in a better position to provide relevant explanations than other social categories. Further target groups were composed of adults and elderly villagers. The study of these social categories provided great insight into their personal understanding and perception of adolescent pregnancy and its determinants. As regards ethical considerations, the principles of anonymity and confidentiality have been strictly respected throughout this research. All of the participants gave informed consent based on a preliminary presentation of the objectives and methods of the study. They were also guaranteed the right to freely withdraw their participation at any point in the course of the research.

Data for analysis was collected by means of group discussions with representatives of the three aforementioned age groups, namely adolescent girls, adults, and seniors. These discussions took the form of structured interviews centred on a particular topic and conducted by a single interviewer with anywhere between six and twelve participants. This kind of interview technique helps researchers to gain a better understanding of the behaviours and attitudes which characterise the social group under study, as explained by Paul (2009). The interviews followed interview guides which had been drafted in advance and were focused on the various sociocultural, socioeconomic, and socioeducational and health factors relevant to the phenomenon of adolescent pregnancy in the village of Anono, as well as on potential solutions for this issue. The seasonal calendar provided an overview of when the villagers would be most available and thereby facilitated the planning of community activities within the scope of the research.

The oral interviews were recorded and the data obtained in this way were transcribed with the aid of the 2016 version of Microsoft Word. Afterwards, they were entered into NVivo 12 for processing. They were classified thematically and subjected to a comparative analysis. Subsequent debriefing with the participants of the study brought the sociological underpinnings of adolescent pregnancy in the village of Anono to light. It was also an occasion to get the whole community to propose collective solutions for this high-risk reproductive behaviour and to agree on an action matrix summarising these solutions and the possible ways of implementing them. Through these discussions, a comprehensive community project aimed at combatting adolescent pregnancy in the village was finalised.

\section{RESULTS AND DISCUSSION}

\subsection{The sociological basis of adolescent pregnancy in the village of Anono}

The sociological basis of adolescent pregnancy in the village of Anono consists of sociocultural, socioeconomic, and socioeducational and health factors. The nine main factors that this study has identified have been classified into these three categories in the synoptic table presented below. 
Community Action in the Fight Against Adolescent Pregnancy in the Village of Anono, Southern Côte d'Ivoire

Table1. The sociological factors of adolescent pregnancy in the village of Anono

\begin{tabular}{|l|l|l|}
\hline Sociocultural factors & Socioeconomic factors & Socioeducational and health factors \\
\hline $\begin{array}{l}\text { grandparents urging adolescents } \\
\text { to procreate }\end{array}$ & family poverty & lack of sexuality education \\
\hline $\begin{array}{l}\text { validation of adolescent } \\
\text { motherhood through the } \\
\text { tambruya ceremony }\end{array}$ & $\begin{array}{l}\text { adolescent girls' financial } \\
\text { insecurity }\end{array}$ & $\begin{array}{l}\text { adolescent girls' ignorance of their } \\
\text { sexuality }\end{array}$ \\
\hline $\begin{array}{l}\text { families ignoring cases of } \\
\text { adolescent rape }\end{array}$ & $\begin{array}{l}\text { adolescent girls exchanging sexual } \\
\text { favours for financial relief }\end{array}$ & failure to use birth control \\
\hline
\end{tabular}

\subsubsection{The Sociocultural Factors of Adolescent Pregnancy in the Village of Anono}

The sociocultural factors of adolescent pregnancy that this study has identified in the village of Anono are grandparents urging adolescents to procreate, validation of adolescent motherhood through the tambruya ceremony, and families ignoring cases of adolescent rape.

It was observed that some grandparents tended to urge their adolescent granddaughters to have children. They were eager to have plenty of descendants and ensure the continuity of the family lineage, and their underage granddaughters were the vehicle through which they pursued this aspiration. In their view, and that of the whole community, adolescent pregnancy did not appear to be a real issue. The local customs and values seemed to tolerate it or even endorse it, as evidenced by the tambruya ceremony, which validates and moreover flaunts adolescent girls' sexuality and their subsequent motherhood. In his study of tambruya in the Ébrié community of Côte d'Ivoire, Egnankou (2019) defines it as a sociocultural practice serving to showcase the social status of primiparas by ritually parading them through the village at the end of a confinement period lasting three months, in the course of which they have been relentlessly fattened. Thus, tambruya is a special privilege enjoyed by primiparas in Ébrié communities, and it applies to adolescent girls too. The relation between such sociocultural factors and adolescent pregnancies has been discussed by Rwenge (1999), cited by Amouzou (2016). The latter shows that sexual practices within a culture are determined by the sociocultural norms and values of the community relating to sexuality and reproduction. These norms and values represent ideological constructs which dictate the development of individual sexual behaviours. In the village of Anono, this kind of ideological context has stimulated sexual activity among local adolescent girls and consequent adolescent pregnancy. Cases of adolescent rape on which families choose to turn a blind eye are another significant cause of adolescent pregnancy which was identified in the sociocultural context of Anono. Not only does rape lead to unwanted pregnancies, it also exposes adolescent girls to sexually transmitted diseases, notably AIDS. Both of these consequences of sexual violence against adolescent girls have been highlighted by Christofides et al. (2014) in the context of South Africa.

Besides sociocultural factors such as these, socioeconomic factors also account for the high rate of adolescent pregnancy in the village of Anono.

\subsubsection{The Socioeconomic Factors of Adolescent Pregnancy in the Village of Anono}

The socioeconomic factors of adolescent pregnancy that this study has identified in the village of Anono are family poverty, adolescent girls' financial insecurity, and adolescent girls exchanging sexual favours for financial relief.

A considerable number of families in the village of Anono did not have adequate financial means to satisfy the basic needs of their children, especially those of their adolescent daughters. As a result, the latter were led to rely on sexual relations as a way to remedy their family's financial plight. Specifically, they would often consent to sexual intercourse with men who could promise them some form of financial relief. In other words, they offered their bodies to obtain the additional income they desperately needed. The same practice has been observed among adolescent girls in rural zones in the Akoupé Department in south-eastern Côte d'Ivoire (Kouadio \& Yao, 2018). The study carried out by Ahuie, Vonan and Dayoro (2016) has also documented the practice in urban regions of the country, specifically in Abobo, one of the communes of Abidjan. The cited authors have argued that exchanging sexual favours for financial relief is the preponderant alternative strategy to which adolescent girls have recourse in order to mitigate their financial insecurity. This socioeconomic practice inevitably exposes adolescent girls to the danger of unwanted pregnancy. Outside of Côte 
d'Ivoire, the phenomenon has been studied in South Africa by Anyanwu et al. (2020), who report that adolescent girls from poor families are highly likely to start having sexual relations early on in life in order to make ends meet, thus incurring the risk of becoming pregnant. However, responsible sexual behaviour, especially the use of contraceptives, can reduce this risk when it is not possible to practice complete abstinence, which has become a popular preventive measure in many contemporary societies.

The exploration of the factors underlying adolescent pregnancy has also brought to light a blatant insufficiency of sexual and reproductive health education and promotion in the village of Anono.

\subsubsection{The Socioeducational and Health Factors of Adolescent Pregnancy in the Village of Anono}

The socioeducational and health factors of adolescent pregnancy that this study has identified in the village of Anono are lack of sexuality education, adolescent girls' ignorance of their sexuality, and failure to use birth control. Specifically, sexual and reproductive health education and promotion is insufficient or utterly lacking in the community of Anono. Adolescent girls therefore suffered from misconceptions regarding the biological link between sexual intercourse and pregnancy and they were ignorant of contraceptive methods, which prevented them from taking the right steps to avoid having an unwanted pregnancy.

The lack of sexuality education was identified at both the familial and the institutional level in the course of the interviews conducted with the participants. It was ascertained that parents failed to talk to their pubescent daughters about sexual matters and to control their sexual behaviours, leaving them to engage in sexual relations without any precautions whatsoever. This lack of communication is largely due to the fact that sexuality is seen as a taboo subject between parents and their children, as indicated by Ahuie, Vonan, and Dayoro (2016). Some parents did address the topic in question with their children, but only so as to reprimand them for what they saw as deviant sexual behaviour (Anyanwu et al., 2020). This occurs in families where the parent-child relationship is based upon the principles of obedience and submission. As such, it leaves little room for useful discussions about sexuality with children. In this regard, Raymond and Poulin (2020) point out that strict parental supervision generally fails to prevent adolescents from engaging in amorous encounters, although it does decrease the likelihood of them having sexual relations once they have acquired a long-term partner.

Outside of the family context, primary and secondary schools teach sexuality, but not responsible sexual behaviour which reduces the risk of unwanted pregnancy and contracting sexually transmitted diseases. Moreover, schools have become sexualised spaces where sexual harassment abounds (Ahuie, Vonan \& Dayoro, 2016; Albenga \& Garcia, 2017; Nsengiyumva, 2018). On the other hand, traditional societies which observe initiation rituals and provide traditional sexuality education are on the whole more successful at establishing social control over their younger members and ensuring that they have relatively unproblematic sex lives (Barou, 2018). Adolescent girls which have been denied even such basic sexuality education and have little to no understanding of their reproductive system cannot be expected to be sexually responsible. Sexuality education is undoubtedly essential for their well-being, but in the village of Anono, they are deprived of it. They end up going through puberty without being taught or advised about the physiological transformations which constitute their process of sexual maturation. This increases their susceptibility to unwanted pregnancy once they venture to start having sexual relations without contraceptive methods.

The development and spread of contraceptive methods has led to more responsible and controlled sexual practices worldwide and has improved sexual and reproductive health in general. The same applies to protective methods which shield against sexually transmitted diseases. However, adolescent girls in the village of Anono tend to desist from such preventive measures and to thus expose themselves to the risk of unwanted pregnancy. Several studies have discussed this phenomenon, pointing out that unfavourable attitudes towards contraception, especially among adolescent girls, can be largely attributed to ignorance (Yidana et al., 2015; Ajayi et al., 2016; Mardi et al., 2018). For instance, Wood and Hendricks (2017) have pointed ot that some adolescent girls wrongly believe that contraceptive methods are meant only for married couples. In light of such data, healthcare professionals must take into account adolescent girls' pre-existing social perceptions and beliefs regarding their body and the implications thereof before undertaking to teach them any biomedical 
facts. For the time being, adolescent girls in the village of Anono lack adequate sexuality education and have patchy or contradictory ideas about the use of contraceptive methods. If they were to start relying on them, they could significantly reduce their risk of unwanted pregnancies, especially if they started taking emergency contraceptives following rape (Ajayi \& Ezegbe, 2020).

Now that the factors underlying adolescent pregnancy in the village of Anono have been elucidated, an overview of the solutions that have been suggested by community members is in order.

\subsection{The Main Solutions for Adolescent Pregnancy Proposed by the Community of Anono}

The discussions between community members of the village of Anono led them to reach several collective decisions with a view to reduce the local rate of adolescent pregnancy. The main solutions which were agreed upon were educating grandparents about adolescent pregnancy, educating adolescents about sexuality, promoting income-generating activities for adolescent girls from poor families, and excluding adolescent girls from the tambruya ceremony.

\subsubsection{Educating Grandparents About Adolescent Pregnancy}

Since it was determined that grandparents are inclined to instigate adolescent pregnancy, the community has decided to educate them and advise them about the dangers and consequences of adolescent pregnancy, so that they could start acting in the interest of their granddaughters' well-being and future rather than to the detriment thereof. In practice, this should involve educational activities aimed at grandparents.

\subsubsection{Educating Adolescent Girls About Sexuality}

As long as adolescent girls engage in sexual activity without having received proper sexuality education, they are exposing themselves to a multitude of social and health problems. Since promoting abstinence in the village of Anono is not a feasible strategy as things currently stand, the community has decided to help educate the youth and adolescents in particular, so that they can at least have safe sexual relations. In practice, this should involve educational activities and workshops centred on sexual and reproductive health education.

\subsubsection{Promoting Income-Generating Activities for Adolescent Girls from Poor Families}

One of the underlying factors of adolescent pregnancy in the village of Anono which this study identified was the poverty of some adolescent girls' families, of which some men took advantage, soliciting sexual favours in exchange for financial relief. In response, the community decided to create and promote income-generating activities for vulnerable adolescent girls.

\subsubsection{Excluding Adolescent Girls From the Tambruya Ceremony}

The tambruya ceremony is a celebration at the end of a three-month confinement period which honours new mothers and their new-borns. It is a special privilege and reflects the whole community's gratitude towards the mother for the child which she has brought into the world. Since the ceremony is open to adolescent girls as well, it indirectly validates adolescent motherhood, but the latter gravely imperils adolescent girls' well-being and future. Consequently, the community of Anono decided to rethink the tambruya ceremony and to completely disqualify adolescent girls from it. This cultural reform will inevitably require further concertation within the community. The resulting custom should restrict the ceremony to women who are aged eighteen or over in order to protect underage girls.

\subsection{Planning of the Community Action and its Implementation}

The involvement of grandparents in improving the well-being of their adolescent granddaughters and in ensuring a better future for them will require the mobilisation of several institutional actors, namely the chieftaincy, the seniors association of Anono, the student youth association of Anono, and the Akan youth union of Côte d'Ivoire. Their role will be to stimulate social change by organising discussions and debates targeting the elderly and centred on the social, economic, and health consequences which adolescent pregnancy entails for both adolescent girls and the community of Anono as a whole. The goal of these discussions is to help the elderly to understand the adversities to which they are subjecting their granddaughters by spurring them to procreate in order to give them great-grandchildren. 
As for sexuality education aimed at adolescents, the community centre, the local hospital, and the student youth association of Anono have been appointed to provide it. Members of the community centre and healthcare workers from the hospital will need to organise workshops intended to teach adolescents about sexual and reproductive health and rectify their pre-existing attitudes and behaviours. The role of the student youth association, in turn, will be to mobilise the youth, encouraging it to take part in the aforementioned educational workshops. Thus, all of these actors will collaboratively strive to help adolescents to acquire knowledge and know-how which would enable them to engage in sexual relations safely and responsibly, without exposing themselves to adverse social or health consequences.

The promotion of income-generating activities aimed at adolescent girls from poor families has been placed in the hands of the student youth association of Anono, the Akan youth union of Côte d'Ivoire, the community centre, and the human resource service centre of the Catholic youth union. Members of the former two associations have been tasked with identifying vulnerable adolescent girls in the village and securing the funding needed to assist them by sending applications to village authorities, communal authorities, regional authorities, and microfinance organisations. As for the latter two entities, they will take charge of adolescent girls' involvement in income-generating activities.

Lastly, the exclusion of adolescent girls from the tambruya ceremony will require efforts on the part of the chieftaincy, the seniors association of Anono, the student youth association of Anono, and the Akan youth union of Côte d'Ivoire. The chieftaincy has been entrusted with the task of enforcing compliance with the reformed version of the ceremony and informing community members that it has been decided that it will be henceforth limited to celebrating adult mothers, no longer applying to adolescent girls. This change is expected to encourage adolescent girls to control their sexual activity as long as they are underage in the hope of later enjoying the privilege of being celebrated by the community upon giving birth to their first child as adults. As for the members of the seniors association of Anono, who are keepers of the values and customs of the community, the student youth association of Anono, and the Akan youth union of Côte d'Ivoire, their role will be to convince the community of the rationale behind the decision to exclude adolescent girls from the tambruya ceremony. For this purpose, the community radio station could be used to broadcast content about the change.

For this community project to bear fruit, monitoring and assessment will be necessary. In the following section, the measures that have been taken in this regard are described.

\subsection{Monitoring and Assessment of Community Action}

A secretariat has been set up for monitoring and keeping track of the community action to be carried out in the village of Anono. Each activity will be recorded in the registers which have been created and monthly reports will be drafted. For the archiving of the data, copies will be addressed to the educational support service division of the community centre of Anono, the human resource service centre of the young Catholic union of Anono, and the respective secretariats of the student youth association of Anono and the Akan youth union of Côte d'Ivoire. To evaluate the effectiveness of the planned community action, several indicators will be relied upon. First of all, the extent of improvement in adolescents' knowledge about sexual and reproductive health and in their use of contraceptive methods will be observed. Secondly, the community's compliance with the decision to exclude adolescent mothers from the tambruya ceremony will be checked. Finally, the guidance and support offered to financially vulnerable adolescent girls and the success of the efforts undertaken to engage them in income-generating activities will be appraised. This type of assessment will make it possible to redress the deficiencies and limitations of the community project so that the objectives which have been set can be attained more effectively.

\subsection{A Critical Examination of Community Engagement in the Fight Against Adolescent Pregnancies in the Village of Anono}

The community project outlined above is based upon the engagement and participation of the community of Anono as a whole. The debriefing with community members successfully mobilised them, getting them to commit to combatting local adolescent pregnancy and to plan appropriate strategies. The expected result is community action which is adapted to the specificities of the local context of the village of Anono in its effort to solve the problem of adolescent pregnancy. This was in 
fact the goal of the participatory action research. However, it should be acknowledged that the community project suffers from undeniable limitations at all stages of its realisation and there is a non-negligible risk of some of the activities being hindered by external obstacles. For instance, it is uncertain whether it is possible to procure sufficient funding for the third proposed solution, promoting income-generating activities for adolescent girls from poor families. The availability of funders cannot be taken for granted. Indeed, the requests filed by the appointed social actors could be declined, in which case the activities that need to be funded would be thwarted. Similarly, the use of birth control is involved in the second proposed solution, educating adolescents about sexuality, but adolescents' access to birth control in the village of Anono might be more or less restricted by geographic distance, by limited availability, or by unaffordable costs. Problems such as these require solutions beyond the ones proposed here for combatting adolescent pregnancy.

\section{CONClusion}

The participatory action research presented in this paper aimed to stimulate community engagement in the fight against adolescent pregnancy in Anono and this paper hopes to have shown the relevance of such an approach. The initial community diagnosis brought to light the sociocultural, socioeconomic, and socioeducational and health factors of the phenomenon in question. The sociocultural factors that were identified were grandparents urging adolescents to procreate, validation of adolescent motherhood through the tambruya ceremony, and families ignoring cases of adolescent rape; the socioeconomic factors were family poverty, adolescent girls' financial insecurity, and adolescent girls exchanging sexual favours for financial relief; and finally, the socioeducational and health factors were lack of sexuality education, adolescent girls' ignorance of their sexuality, and failure to use birth control. The debriefing with community members enabled them to get to grips with this range of factors. Subsequently, community members themselves devised four main solutions for adolescent pregnancy, adapted to the local context: educating grandparents about adolescent pregnancy, educating adolescents about sexuality, promoting income-generating activities for adolescent girls from poor families, and excluding adolescent girls from the tambruya ceremony. The implementation of these high-priority measures will require community action. For this community project to come to fruition, the engagement and participation of the whole community of Anono is necessary. Their joint efforts would guarantee a successful reduction of the high rate of adolescent pregnancy in the village.

\section{ACKNOWLEDGEMENTS}

The authors are grateful to the population of the village of Anono for many hours devoted to this study, disponibility and collaboration during the data collection period.

\section{REFERENCES}

[1] World Health Organization. (2020). La grossesse chez les adolescentes. [Teenage pregnancy]. Genève: Organisation mondiale de la Santé, Centre des médias, Principaux repères sur la grossesse chez les adolescentes. Retrieved January 20, 2021 from https://www.who.int/fr/news-room/fact-sheets/detail/ adolescent-pregnancy.

[2] World Health Organization. (2012). Prévenir les grossesses précoces et leurs conséquences en matière de santé reproductive chez les adolescentes dans les pays en développement : les faits. [Preventing early pregnancy and poor reproductive outcomes among adolescents in developing countries : what the evidence says]. World Health Organization, pp. 1-8. Retrieved January 20, 2021 from https://apps.who.int/iris/ handle/10665/75466

[3] McIntyre, P., \& World Health Organization . (2007). Adolescentes enceintes : apporter des promesses globales d' espoir. [Pregnant adolescents : delivering on global promises of hope ]. Genève : Organisation mondiale de la Santé , pp. 1-32. Retrieved January 20, 2021 from https://apps.who.int/iris/handle/ $10665 / 43650$

[4] United Nations Population Fund (UNFPA). (2015). Girlhood, not motherhood: preventing adolescent pregnancy. New York, USA: UNFPA, pp. 1-62. Retrieved January 20, 2021 from https://www.unfpa. org/sites/default/files/pub-pdf/Girlhood_not_motherhood_final_web.pdf

[5] Ministère de la santé et de l'hygiène publique (MSHP). (2016). Plan national de développement sanitaire 2016-2020. [National Health Development Plan 2016-2020]. Abidjan, République de Côte d'Ivoire: Draft Consolidé, pp. 1-88.Retrieved January 20, 2021 from https://www.childrenandaids.org/sites/default/files/ 2017-11/pnds_2016-2020.pdf 
[6] Ministère de la santé et de la lutte contre le sida (MSLS), l'institut national de la statistique (INS) et ICF international. (2012). Enquête Démographique et de Santé et à Indicateurs Multiples de Côte d'Ivoire 2011-2012 : Rapport préliminaire. [Côte d'Ivoire Demographic and Health Survey and Multiple Indicator Cluster Survey 2011-2012: Preliminary Report]. MSLS, INS et ICF International, Calverton, Maryland, USA, p. 1-561. Retrieved January 20, 2021 from https://www.dhsprogram.com/pubs/pdf/FR272/ FR272.pdf

[7] OECD Development Centre. (2017). Examen du bien-être et des politiques de la jeunesse en Côte d'Ivoire. [Review of youth welfare and policies in Côte d'Ivoire]. Projet OCDE-UE Inclusion des jeunes, Paris, pp. 1-119. Retrieved January 20, 2021 from https://www.oecd.org/countries/cotedivoire/Examen-du\%20bienetre-et-des-politiques-de-la-jeunesse-en-Cote-dIvoire.pdf

[8] Rwenge, M. (1999). Facteurs contextuels des comportements sexuels: le cas des jeunes de la ville de Bamenda (Cameroun). [Contextual Factors of Sexual Behavior: The Case of Youth in the City of Bamenda, Cameroon]. Bioline International, Rapport de synthèse (Union for African Population Studies), 40. Retrieved January 20, 2021 from www.bioline.org.br/request?uaps 99040.

[9] Blum, R., \& Gates, W. H. (2013). A global look at adolescent pregnancy prevention: Strategies for success. Office of adolescent health webcast, pp. 1-39. Retrieved January 20, 2021 from https:// fr.slideshare.net/OfficeOfAdolescentHealth/a-global-look-at-teen-pregnancy-prevention

[10] Yakubu, I., \& Salisu, W. J. (2018). Determinants of adolescent pregnancy in sub-Saharan Africa: a systematic review. Reproductive Health, 15(15), 1-11. https://doi.org/10.1186/s12978-018-0460-4

[11] Mchunu, G., Peltzer, K., Tutshana, B., \& Seutlwadi, L. (2012). Adolescent pregnancy and associated factors in South African youth. African health sciences, 12(4), 426-434. http://dx.doi.org/10.4314/ ahs.v12i4.5

[12] Ogori, A. F., Shitu, F., \& Yunusa, A. R. (2013). The cause and effect of teenage pregnancy: case of Kontagora Local Government Area in Niger state Northern part of Nigeria. International open journal of educational research, 1(7), 1-15. http://acascipub.com/Journals.php

[13] Krugu, J. K., Mevissen, F. E. F., Prinsen, A., \& Ruiter, R. A. (2016). Who's that girl? A qualitative analysis of adolescent girls' views on factors associated with teenage pregnancies in Bolgatanga, Ghana. Reproductive health, 13(39), 1-12. https://doi.org/10.1186/s12978-016-0161-9

[14] Wood, L., \& Hendricks, F. (2017). A participatory action research approach to developing youth-friendly strategies for the prevention of teenage pregnancy. Educational action research, 25(1), 103-118. http:// dx.doi.org/10.1080/09650792.2016.1169198

[15] Salami, K. K., Ayegboyin, M., \& Adedeji, I. A. (2014). Unmet social needs and teenage pregnancy in Ogbomosho, South-western Nigeria. African health sciences, 14(4), 959-966. http://dx.doi.org/10.4314 /ahs.v14i4.27

[16] Mushwana, L., Monareng, L., Richter, S., \& Muller, H. (2015). Factors influencing the adolescent pregnancy rate in the greater Giyani Municipality, Limpopo Province-South Africa. International Journal of Africa Nursing Sciences, 2, 10-18. https://doi.org/10.1016/j.ijans.2015.01.001

[17] McCleary-Sills, J., Douglas, Z., Rwehumbiza, A., Hamisi, A., \& Mabala, R. (2013). Gendered norms, sexual exploitation and adolescent pregnancy in rural Tanzania. Reproductive health matters, 21(41), 97105. https://doi.org/10.1016/S0968-8080(13)41682-8

[18] Atuyambe, L. M., Kibira, S. P., Bukenya, J., Muhumuza, C., Apolot, R. R., \& Mulogo, E. (2015). Understanding sexual and reproductive health needs of adolescents: evidence from a formative evaluation in Wakiso district, Uganda. Reproductive health, 12(35), 1-10. https://doi.org/10.1186/s12978-015-0026-7

[19] Gyan, C. (2013). The effects of teenage pregnancy on the educational attainment of girls at Chorkor, a suburb of Accra. Journal of Educational and Social Research, 3(3), 53-60. https://doi.org 10.5901/jesr.201 3.v4n3p53

[20] Lambani, M. N. (2015). Poverty the cause of teenage pregnancy in Thulamela municipality. Journal of Sociology and Social Anthropology, 6(2), 171-176. https://doi.org/10.1080/09766634.2015.11885656

[21] Jewkes, R., Vundule, C., Maforah, F., \& Jordaan, E. (2001). Relationship dynamics and teenage pregnancy in South Africa. Social science \& medicine, 52(5), 733-744. https://doi.org/10.1016/S0277-9536(00) 00177-5

[22] Warenius, L. U., Faxelid, E. A., Chishimba, P. N., Musandu, J. O., Ong'any, A. A., \& Nissen, E. B. (2006). Nurse-midwives' attitudes towards adolescent sexual and reproductive health needs in Kenya and Zambia. Reproductive health matters, 14(27), 119-128. https://doi.org/10.1016/S0968-8080(06)27242-2

[23] Okigbo, C. C., \& Speizer, I. S. (2015). Determinants of sexual activity and pregnancy among unmarried young women in urban Kenya: a cross-sectional study. PloS one, 10(6), e0129286. https://doi.org/10.1371 /journal.pone.0129286. 
[24] Townsend, E., Birch, D. E., Langley, J., \& Langille, L. (2000). Participatory research in a mental health clubhouse. The Occupational Therapy Journal of Research, 20(1), 18- 44. https://doi.org/10.1177/15394 4920002000102

[25] Rains, J. W., \& Ray, D. W. (1995). Participatory action research for community health promotion. Public Health Nursing, 12(4), 256-261. https://doi.org/10.1111/j.1525-1446.1995.tb00145.x

[26] Mason, R., \& Boutilier, M. (1996). The challenge of genuine power sharing in participatory research: The gap between theory and practice. Canadian Journal of Community Mental Health, 15(2), 145-152.

[27] Reason, P. (1994). Three approaches to participative inquiry. In N. K. Denzin \& Y. S. Lincoln (Eds.), Handbook of qualitative research (p. 324-339). Sage Publications, Inc.

[28] Hagey, R. S. (1997). La recherche participative: utilité et abus. [Participatory Research: Utility and Abuse]. Maladies chroniques au Canada, 18(1), 1-5.

[29] Park, P., Brydon-Miller, M., Hall, B., Jackson, T., \& Freire, P. (1993). What is participatory research? A theoretical and methodological perspective. Voices of change: Participatory research in the United States and Canada, 1.

[30] Green, L., Daniel, M., \& Novick, L. (2001). Partnerships and coalitions for community-based research. Public health reports, 116(Suppl 1), 20. 20-31. doi: 10.1093/phr/116.S1.20

[31] Sullivan, M., Kone, A., Senturia, K. D., Chrisman, N. J., Ciske, S. J., \& Krieger, J. W. (2001). Researcher and researched-community perspectives: Toward bridging the gap. Health Education \& Behavior, 28(2), 130-149. https://doi.org/10.1177/109019810102800202

[32] Demange, E., Henry, E., \& Préau, M. (2012). De la recherche en collaboration à la recherche communautaire. Un guide méthodologique. [From collaborative to community-based research. A methodological guide]. Paris, ANRS/Coalition Plus pp. 1-214. http://www.plateforme-elsa.org/wp-content /uploads/2014/03/GUIDEfr.pdf

[33] Brenoum, K. D., Dihouegbeu, D. P., Kobenan, A. C., \& Atta, K. (2017). Anono : Du village au quartier dortoir (Abidjan-Côte d'ivoire). [Anono: From the village to the dormitory district (Abidjan-Côte d'ivoire)]. Revue Ivoirienne de Géographie des Savanes, 3, 209-224. https://riges-uao.net/volumes/ volume3/fichiers/art14.pdf

[34] Paul, G. (2009). Le groupe de discussion. [The focus group]. In Gauthier, B., Recherche sociale: de la problématique à la collecte des données. Puq, 5ème ed., Québec, pp. 391-414.

[35] Egnankou, A. P. (2019). Refus du gavage et nouvelles normativités alimentaires des femmes ébrié de Côte d'Ivoire. [Refusal of force-feeding and new food standards for Ébrié women in Côte d'Ivoire]. Revue des sciences sociales, (61), 78-87. https://doi.org/10.4000/revss.3767

[36] Amouzou M. (2016). Statut migratoire et grossesse à risques des adolescentes a la périphérie de Ouagadougou. [Migratory status and high-risk teenage pregnancy on the outskirts of Ouagadougou]. In Trajectoires et âges de la vie (Sélection d'articles issus des travaux présentés au XVIIIe colloque, Bari, 2014, pp. 1-17. https://www.erudit.org/en/books/actes-des-colloques-de-lassociation-internationale-desdemographes-de-langue-francaise/trajectoires-ages-vie-selection-darticles-issus-travaux-presentes-auxviiie--978-2-9521220-5-4/000399li.pdf

[37] Christofides, N. J., Jewkes, R. K., Dunkle, K. L., Nduna, M., Shai, N. J., \& Sterk, C. (2014). Early adolescent pregnancy increases risk of incident HIV infection in the Eastern Cape, South Africa: a longitudinal study. Journal of the International AIDS Society, 17(1), 18585. https://doi.org/10.7448/IAS. 17.1.18585

[38] Kouadio, K. C., \& Yao N. L. F. (2018). Régards croisés sur les déterminants des risques de survenue des grossesses précoces chez les jeunes filles dans la région d'Akoupe. [Crossed views on the determinants of the risks of early pregnancy among young girls in the Akoupe region]. Revue Africaine d'Anthropologie Nyansa-Pô, 27, 235-259. http://revues-ufhb-ci.org/fichiers/FICHIR_ARTICLE_2404.pdf

[39] Ahuie, A. A. C., Vonan, A. P. C., \& Dayoro, Z. A. K. (2016). Précocité sexuelle des adolescents et grossesse en milieu scolaire. Une étude réalisée dans la commune d'Abobo (Côte d'Ivoire). [Sexual precocity of the teenagers and pregnancy in school. a study carried out in the commune of abobo (Ivory Coast)]. Revue ivoirienne d'anthropologie et sociolociologie, Kasa Bya Kasa, 33, 111-127. http://revuesufhb-ci.org/fichiers/FICHIR_ARTICLE_2350.pdf

[40] Anyanwu, F. C., Akinsola, H. A., Tugli, A. K., \& Obisie-Nmehielle, N. (2020). A qualitative assessment of the influence of family dynamics on adolescents' sexual risk behaviour in a migration-affected community. International journal of qualitative studies on health and well-being, 15(1), 1717322, 1-12. https://doi.org/10.1080/17482631.2020.1717322

[41] Raymond, M., \& Poulin, F. (2020). Avoir des relations sexuelles (ou non) avec son partenaire amoureux à l'adolescence : Contribution des pratiques parentales et caractéristiques de la relation de couple [Having 
sex (or not) with your romantic partner in adolescence: Contribution of parenting practices and characteristics of the couple relationship]. Canadian Journal of Behavioural Science / Revue canadienne des sciences du comportement, 52(4), 267-276. https://doi.org/10.1037/cbs0000171

[42] Albenga, V. \& Garcia, M. (2017). Chapitre 9. La sur-responsabilisation des filles dans « l'éducation à la sexualité » : une norme scolaire asymétrique. [The over-responsibility of girls in "sexuality education": an asymmetrical school norm]. Dans : Hélène Buisson-Fenet éd., École des filles, école des femmes: L'institution scolaire face aux parcours, normes et rôles professionnels sexués. Louvain-la-Neuve, Belgique: De Boeck Supérieur, pp. 151-163. https://www.cairn.info/ecole-des-filles-ecole-des-femmes-9782807305670-page-151.htm

[43] Nsengiyumva, A. (2018). Du sexe en echange des points en milieu scolaire: La pratique de Kwideribera. [Sex in exchange for points in school: The practice of Kwideribera]. L'Homme-Revue française d'anthropologie. Éditions de l'EHESS 2018, pp. 1-18. https://halshs.archives-ouvertes.fr/halshs-01804866 /document

[44] Barou, J. (2018). Répression ou liberté... sous contrôle. [Repression or freedom... under control].L'école des parents, 1(1), 58-60. https://doi.org/10.3917/epar.626.0058

[45] Yidana, A., Ziblim, S. D., Azongo, T. B., \& Abass, Y. I. (2015). Socio-cultural determinants of contraceptives use among adolescents in northern Ghana. Public Health Research 2015, 5(4): 83-89. DOI: 10.5923/j.phr.20150504.01

[46] Ajayi, A. I., Nwokocha, E. E., Akpan, W., \& Adeniyi, O. V. (2016). Use of non-emergency contraceptive pills and concoctions as emergency contraception among Nigerian University students: results of a qualitative study. BMC Public Health, 16(1046), 1-8. https://doi.org/10.1186/s12889-016-3707-4.

[47] Mardi, A., Ebadi, A., Shahbazi, S., \& Moghadam, Z. B. (2018). Factors influencing the use of contraceptives through the lens of teenage women: a qualitative study in Iran. BMC public health, 18(202), 1-8. https://doi.org/10.1186/s12889-018-5116-3

[48] Ajayi, A. I., \& Ezegbe, H. C. (2020). Association between sexual violence and unintended pregnancy among adolescent girls and young women in South Africa. BMC public health, 20(1370), 1-10. https://doi.org/10.1186/s12889-020-09488-6

Citation: Adou Serge Judicaël Anoua, et.al. "Community Action in the Fight Against Adolescent Pregnancy in the Village of Anono, Southern Côte d'Ivoire" International Journal of Research in Sociology and Anthropology (IJRSA), vol 6, no. 3, 2020, pp. 16-26. doi: https://doi.org/10.20431/2454-8677.0603003.

Copyright: (C) 2020 Authors. This is an open-access article distributed under the terms of the Creative Commons Attribution License, which permits unrestricted use, distribution, and reproduction in any medium, provided the original author and source are credited. 